\title{
Nutritional, Functional, Physical, and Microstructural Properties of Ethiopian Emmer Wheat (Triticum dicoccum L.) Varieties as Affected by Growing Seasons and Grain Types (Hulled and Dehulled)
}

\author{
Bethlehem Melese, ${ }^{1,2}$ Neela Satheesh $\mathbb{D}^{1},{ }^{1,3}$ Solomon Workneh Fanta $\mathbb{D}^{1},{ }^{1}$ \\ and Zewdie Bishaw $\left.{ }^{4}\right)^{4}$ \\ ${ }^{1}$ Department of Postharvest Technology, Faculty of Chemical and Food Engineering, Bahir Dar Institute of Technology, \\ Bahir Dar University, Bahir Dar, Ethiopia \\ ${ }^{2}$ Wondogenet Research Center, Ethiopian Institute of Agricultural Research, Wondogenet, Ethiopia \\ ${ }^{3}$ Department of Food Nutrition and Dietetics, Faculty of Agriculture, Sri Sri University, Cuttack, Odisha, India \\ ${ }^{4}$ International Center for Agricultural Research, Dry Areas, Addis Ababa, Ethiopia
}

Correspondence should be addressed to Solomon Workneh Fanta; solworkneh@gmail.com

Received 12 September 2021; Revised 20 December 2021; Accepted 5 February 2022; Published 27 February 2022

Academic Editor: Marina Carcea

Copyright $\odot 2022$ Bethlehem Melese et al. This is an open access article distributed under the Creative Commons Attribution License, which permits unrestricted use, distribution, and reproduction in any medium, provided the original work is properly cited.

\begin{abstract}
This study was conducted to evaluate the effect of the growing seasons, grain types, and varieties on physical, proximate, functional, mineral, vitamins, amino acids, and microstructural properties of Ethiopian emmer wheat. One local landrace and three improved emmer wheat varieties (Hydroo, Sinana 01, and Lameso) grown during Meher and Belg seasons and grain types (hulled and dehulled) were used for analysis. The study showed that dehulled Sinana 01 variety from Belg season had the highest (17.82\%) protein content. Varieties grown in Belg season showed the highest mineral compositions. The essential amino acids in emmer wheat were higher in the hulled grain type grown in Meher season. The highest vitamin B1 $(0.17 \mathrm{mg} / \mathrm{g}), \mathrm{B} 2(0.35 \mathrm{mg} / \mathrm{g})$, and B6 $(5.52 \mathrm{mg} / \mathrm{g})$ contents were observed in hulled emmer wheat types grown in Meher season. The study concluded that seasonal variation, grain types, and varieties have a great effect on the proximate, physical, and functional properties of emmer wheat cultivated in Ethiopia.
\end{abstract}

\section{Introduction}

Wheat is an important food crop cultivated worldwide for human consumption providing energy and vital nutrients. Different wheat species including bread wheat (Triticum aestivum L.), durum wheat (Triticum turgidum L. var. durum), einkorn wheat (Triticum monococcum L.), and emmer wheat (Triticum dicoccum L.) are growing all over the world [1].

Emmer wheat was the earliest domesticated species [2] and the principal wheat type of the ancient world including Europe during the Neolithic and early Bronze ages. In Africa, emmer wheat was first cultivated in Morocco and gradually reached Egypt during the fifth century BC. It was introduced to Ethiopian highlands around 5,000 years ago [2]. At the beginning of the twentieth century, emmer wheat was mostly replaced by improved bread and durum wheat varieties due to the threshing problems and lower yields [3]. To date, emmer wheat has covered only $1 \%$ of the total wheat area in the world and is cultivated mainly in Ethiopia, Iran, India, Eastern Turkey, Italy, Spain, and Central Europe. It is still considered an important crop in India, Ethiopia, and Yemen [3].

Although grown in some countries, emmer wheat is among underutilized cereal crops. However, it has a considerable importance in food security and cultural significance and is utilized in traditional food preparations in many countries including Ethiopia. There has been renewed 
interest in emmer wheat in recent years as a valuable source of biologically active compounds like dietary fiber, protein, vitamins, minerals, and antioxidants [4]. Emmer wheat was recognized as a very healthy cereal and recommended in the diet of people suffering from allergies, colitis, and high blood cholesterol levels [5].

Ethiopia has a suitable environment for cultivation of the emmer wheat. The crop is cultivated on marginal areas in Bale, Arsi, Shewa, Harerge, Wollo, Gojam, Gondar, and Tigray. According to the Central Statistical Agency [6], emmer wheat covered about 24000 hectares with production of 492000 quintals in 2016 and represented about $7 \%$ of the country's wheat production. Bale zone in southeastern Ethiopia has a potential for emmer wheat production where the crop is grown in both "Meher" (June to September) and "Belg" (March to May) seasons [7]. In Bale zone, emmer wheat is consumed after it is dehusked by traditional practices and ground into flour and used to prepare nonfermented flat bread known as "Kita." Emmer wheat producing farmers and consumers in Bale zone and elsewhere in the country strongly believe that it has some medicinal values. They believe that broken bones heal faster by consumption of emmer wheat. It is also recommended for mothers as a special diet to maintain health and strength after childbirth [8].

Ethiopian emmer wheat is considered to have unique features compared to emmer wheat produced in other parts of the world. However, the nutritional, physical, functional, and antioxidant properties of cultivated Ethiopian emmer wheat are not studied and scientifically documented information is not available yet. Therefore, the aim of this study was to determine the influence of growing seasons and grain types (hulled and dehulled) on the nutritional, functional, and physical properties of Ethiopian emmer wheat varieties.

\section{Materials and Methods}

\subsection{Emmer Wheat Sample Collection and Preparation.} The emmer wheat seed samples were collected from Sinana Agricultural Research Centre (SARC) located $33 \mathrm{~km}$ away from Robe (capital city of Bale zone) and $463 \mathrm{~km}$ from Addis Ababa (capital city of Ethiopia). SARC is located at $70^{\circ} \mathrm{N}$ latitude and $40^{\circ} \mathrm{E}$ longitude with an elevation of 2400 meters above sea level and mean annual rainfall of $812 \mathrm{~mm}$ with a bimodal pattern. Belg is the short rainy period for most part of Ethiopia; it covers the period from February to April. Rainfall during the season is highly variable in time and space and the maximum temperature is $28.1^{\circ} \mathrm{C}$. From Belg season, March and April months are the warmest months. Meher is the main rainy season; it covers the period from May to September. This season is associated with frequent rain and homogeneous temperatures mainly in July and August. The mean maximum temperature is $26^{\circ} \mathrm{C}$. The magnitude of rainfall is higher as compared to the Belg season. The predominant soil types at SARC are Phaeozems and Cambisols with minor occurrence of Vertisols. The soils are deep, fine textured, and have aggregated soil structure with good porosity. Emmer wheat cultivation is practiced in both "Meher" and "Belg" seasons.

Grain samples of three improved emmer wheat varieties (Lameso, Sinana 01, and Hydroo) and one local landrace were collected from SARC from crops grown during the Meher and Belg seasons in 2019. For each variety and landrace, one sample produced during the Meher season and one sample produced during Belg season were sampled. All emmer wheat samples produced during different seasons were collected separately and cleaned manually to remove dust, stones, straw, and other impurities. The collected samples were packed carefully and protected from loss of moisture. Each cleaned emmer wheat sample was divided into two parts. One part remained hulled, while the remaining half was dehulled manually using the traditional practice as reported by Melese et al. [7]. Both the hulled and dehulled samples were packed separately in polyethylene bags. A part of the samples were ground into flour by UDY Cyclone Mill (Fort Collins, CO, USA) and passed through a $<1 \mathrm{~mm}$ sieve, and samples were packed in polyethylene bag and preserved at $4^{\circ} \mathrm{C}$. The ground seed sample was used for determination of different properties of the emmer wheat. The remaining samples were used for the analysis of physical properties. The analysis was completed as soon as possible.

2.2. Experimental Design. The experiment consisted of three factors with factorial arrangement and was designed in CRD. The first factor variety was considered with four levels (Hydroo, Lameso, Sinana 01, and local). The second factor cropping season was considered with two levels (Meher and Belg) and the third factor grain type was considered with two levels (hulled and dehusked). All treatments were analysed in triplicate and the total runs conducted in this experiment were 48 .

2.3. Determination of Physical Properties. Physical properties such as thousand grain weight (TGW), seed length and width, bulk density, and porosity were determined according to the procedures reported by Chowdhury et al. [9] and true density was determined by the method of Tavakoli et al. [10].

\subsection{Determination of Proximate Composition and Gluten} Content. Different methods were used to determine proximate and gluten content of emmer wheat seed samples. The moisture content of seed samples was measured by the hot air oven method gravimetrically [11], method number 925.10); protein content by Kjeldahl method [11], method number 979.09) with a conversion factor of 5.7; fiber content by nonenzymatic gravimetric method [11], method number 920.168); and fat content by using Soxhlet extraction method where hexane used as the solvent. Total ash content was determined using the incineration method by muffle furnace [11], method number 923.03); carbohydrates determination by difference method [12]; and energy determination by [13]. Extraction and weighing methods were used for gluten content determination [14]. 
2.5. Determination of Mineral Compositions. To determine the mineral compositions, $4 \mathrm{~g}$ emmer wheat flour was mixed with $30 \mathrm{ml}$ of aqua regia (mixture of nitric acid and hydrochloric acid in a molar ratio of $1: 3$ ). The mixture was sonicated in an ultrasonic bath for 15 minutes, made up to $25 \mathrm{ml}$, and mixed with deionized water. The resulting sample solutions were centrifuged for 10 minutes, and the supernatants were taken for determination of minerals by ICPOES [15].

2.6. Determination of Amino Acid Composition. High Performance Liquid Chromatography (HPLC) was used to determine the amino acid composition following a procedure given by AOAC [11]. The screw capped test tube flushed by nitrogen and cleaned with $0.1 \mathrm{M} \mathrm{HCL}$ was used for the hydrolysis. Each sample weighing $0.2 \mathrm{~g}$ was placed in the test tubes containing $12 \mathrm{ml}$ of $6 \mathrm{M} \mathrm{HCL}$. The tubes containing the seed samples and HCL were placed in an oven for 24 hours to complete hydrolysis. The samples were taken out from the oven, cooled to room temperature, and dried to remove HCL. Then, the samples were reconstituted again in $3 \mathrm{ml}$ of $0.02 \mathrm{M} \mathrm{HCL}$ and filtered through $0.22 \mu \mathrm{m}$ filter paper prior to centrifugation.

2.7. Vitamin B Complex Analysis. For vitamin B complex determination, the method reported by Ndaw et al. [16] was used. A seed (grain) sample weighing $2.5 \mathrm{~g}$ was placed in a $100 \mathrm{ml}$ reagent bottle. $25 \mathrm{ml}$ of $0.05 \mathrm{~mol} / \mathrm{L}$ sodium acetate ( $\mathrm{pH} 4.5$ ) was added to the sample, followed by a mixture of papain $(50 \mathrm{mg}), 1 \%$ glutathione $(250 \mu \mathrm{L})$, acid phosphatase $(10 \mathrm{mg})$, and $a$-amylase ( $5 \mathrm{mg}$ ). The samples were mixed and incubated in a shaker at $37^{\circ} \mathrm{C}$ for $20 \mathrm{~h}$ and then diluted with distilled water in a $50 \mathrm{~mL}$ volumetric flask. The supernatant was filtered through filter paper. The filtrate obtained after a second filtration through a cellulose acetate filter $(0.2 \mu \mathrm{m})$ was used for chromatographic determination of vitamin $\mathrm{B}$.

To determine other vitamins, an aliquot of the first filtrate $(2 \mathrm{ml})$ was added to a $10 \mathrm{~mL}$ tube with an alkaline solution of potassium ferricyanide $(2 \mathrm{~mL})$. The mixture was agitated and then allowed to stand for exactly 5 minutes. $2 \mathrm{ml}$ of butanol was added with vortexing and stratification of the tube allowed. An HPLC with RF10Axl fluorescence detector was used to determine the contents of vitamins B1, B2, B3, and B6.

\subsection{Determination of Antinutritional Factors}

2.8.1. Phytate. The method described by Vaintraub and Lapteva [17] was used for determination of phytate content. Five grams of seed dried sample was weighed and extracted with $10 \mathrm{ml}$ of $2 \mathrm{~N} \mathrm{HCl}$ for $1 \mathrm{hr}$ at ambient temperature and centrifuged at $1107 \mathrm{xg}$ for 30 minutes to form a supernatant sample solution. Then $2 \mathrm{ml}$ of wade reagent was mixed with $3 \mathrm{ml}$ of the supernatant sample solution, homogenized, and centrifuged at $1107 \mathrm{xg}$ for $10 \mathrm{~min}$. The absorbance was measured at $500 \mathrm{~nm}$ in a double beam UV-Vis spectrophotometer. The phytate content was calculated from the difference between the absorbance of the blank ( $3 \mathrm{ml}$ of $0.2 \mathrm{~N}$ $\mathrm{HCl}+2 \mathrm{ml}$ of wade reagent) and the sample. The amount of phytic acid was calculated by using the phytic acid standard curve and the result expressed as phytic acid in $\mu \mathrm{g} / \mathrm{g}$ fresh weight.

2.8.2. Tannin. The reported method by Maxson and Rooney (1972) was used for condensed tannin determination. One gram of sample was added in a screw cap centrifuge tube and $10 \mathrm{ml}$ of $1 \% \mathrm{HCl}$ in methanol was mixed in the sample containing tubes. The tubes were closed with a lid and allowed to shake on a mechanical shaker for $24 \mathrm{hr}$ at room temperature. The mixture was centrifuged at $123 \mathrm{xg}$ for 5 minutes and $1 \mathrm{ml}$ supernatant was mixed with $5 \mathrm{ml}$ of vanillin $\mathrm{HCl}$ reagent in another test tube and left for 20 minutes until the reaction was completed and the absorbance was taken at $500 \mathrm{~nm}$ using double beam UV-Vis spectrophotometer. The tannin content was calculated by using a standard curve and the result was expressed as $\mathrm{mg} / \mathrm{g}$.

2.9. Determination of Molar Bioavailability of Minerals ( $\mathrm{Ca}$, $\mathrm{Fe}$, and $\mathrm{Zn}$ ). The molar ratio of phytate to minerals ( $\mathrm{Ca}, \mathrm{Zn}$, and $\mathrm{Fe}$ ) was calculated by dividing the mole of phytate (mass of phytate $/ 660 \mathrm{~g} / \mathrm{mol}$ ) by the mole of minerals (Ca $40 \mathrm{~g} / \mathrm{mol}$; Zn 65 g/mol; Fe 56 g/mol) [18].

\subsection{Determination of Antioxidant Property (DPPH Method).} The DPPH free radical scavenging method was used to measure antioxidant properties. A $60 \mu \mathrm{mol} / \mathrm{L}$ DPPH reactant was made in methanol and $3.9 \mathrm{ml}$ of DPPH solution was added to $0.1 \mathrm{ml}$ of sample. The absorbance at $515 \mathrm{~nm}$ was measured immediately and after 60 minutes of incubation. A plot of Trolox concentration against DPPH scavenging activity was used as the standard curve and antioxidant activity was expressed as the micromole equivalent of Trolox/g [19].

2.11. Scanning Electron Microscope Imaging of Grains. Acetone was used to clean the sample holder and carbon graphite tips were cut in small pieces and sticked to samples. These fine powder samples are fastened on the sample holder and then inserted into Scanning Electron Microscopy (SEM; INSPECT F50) by using tweezers. The vacuum systems were pumped to create under vacuum and once vacuum pressure reached $1 \times 10^{-3}$ pa the sample name was annotated. Finally, by adjusting the breathiness, stigmatism, contrast, focusing, magnification, working distance, working voltage, and spot size, surface morphology analysis was done [14].

2.12. Data Analysis. All the collected data was subjected to statistical analysis. The analysis of variance (ANOVA) was carried out using SAS version 9.3 software. Significant differences between treatment means were delineated by LSD test at 5\% level of significance. 


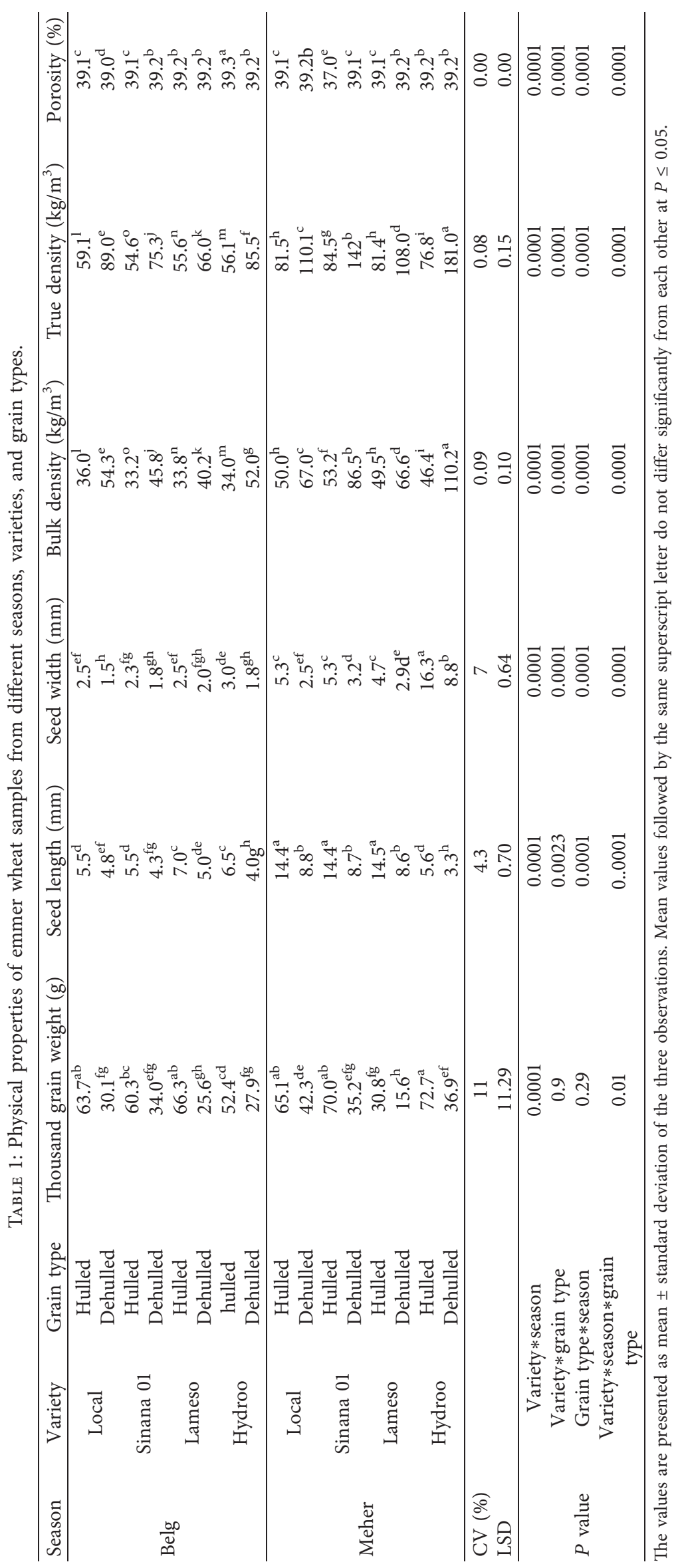




\section{Results and Discussions}

3.1. Effect of Growing Season, Grain Type, and Variety on Physical Properties of Emmer Wheat. In this section, the results of the physical properties of emmer wheat varieties are presented and discussed (Table 1).

3.1.1. Thousand Grain Weight. The TGW is an important yield parameter of emmer wheat. ANOVA revealed that the interaction of grain types, growing seasons, and varieties had a significant $(P \leq 0.05)$ effect on TGW (Table 1$)$. The highest TGW $(72.75 \mathrm{~g})$ was observed for the hulled Hydroo variety from Meher season, whereas the lowest $(15.58 \mathrm{~g})$ was observed for the dehulled Lameso variety from the same growing season. Hejcman and Hejcmanová [20] also reported significant interaction of season and genotype on TGW of emmer wheat varieties. Similar results were also reported for bread wheat [21] and durum wheat [22]. Grain weight is a genetic character where different genotypes exhibit differences in grain size and weight.

3.1.2. Seed Length. Seed length can be used to characterize seed and consumer acceptability. There is a significant $(P \leq 0.05)$ effect of growing season, varieties, and grain types on emmer wheat's seed length (Table 1). The seed length values ranged from $14.4 \mathrm{~mm}$ to $3.3 \mathrm{~mm}$. The seed length of hulled local landrace, Sinana 01, and Lameso grown in Meher season was the longest $(14.4 \mathrm{~mm})$, whereas that of the dehulled Hydroo variety grown in the same season was observed to be the shortest $(3.3 \mathrm{~mm})$ (Table 1$)$. Similarly, Kolankowska et al. [23] also reported that hulled emmer wheat had the longest $(15.99 \mathrm{~mm})$ seed length, whereas the dehulled grain showed the shortest $(11.99 \mathrm{~mm})$. The variations in seed length were attributed to the genetic factors and environmental conditions during the growing season. Seed length had an impact on crop yield and kernel plumpness and physical properties of seeds (length, width, thickness, and mass) [23].

3.1.3. Seed Width. The interaction of grain type, growing season, and variety showed a significant $(P \leq 0.05)$ effect on seed width (Table 1). The seed width of emmer wheat varieties ranged from $16.3 \mathrm{~mm}$ to $1.5 \mathrm{~mm}$. The hulled Hydroo variety grown in Meher season showed the biggest seed width $(16.3 \mathrm{~mm})$, whereas the dehulled local variety grown in Belg season had the smallest seed width $(1.5 \mathrm{~mm})$. Kolankowska et al. [23] reported that hulled emmer wheat showed a bigger $(6.88 \mathrm{~mm})$ width than the dehulled grain and reported that growing conditions have the greatest effect on seed width, length, and thickness.

3.1.4. Bulk Density. Bulk density is a useful property to determine designing seed hopper dimensions in seed planters, cleaning, and grading equipment and the required storage capacity. The interactions of all the studied factors had significantly affected $(P \leq 0.05)$ the bulk density of emmer wheat (Table 1$)$. The highest bulk density $(110.2 \mathrm{~kg} /$ $\mathrm{m}^{3}$ ) was observed for dehulled Hydroo variety grown in Meher season. In contrast, the lowest bulk density $(33.2 \mathrm{~kg} /$ $\mathrm{m}^{3}$ ), was recorded by hulled Sinana 01 variety grown in Belg season. Emmer wheat varieties grown in Meher season showed higher bulk density than those grown in Belg season and dehulled grains had the lowest bulk density compared to hulled ones. Significantly higher bulk densities were reported for wheat $\left(804.44 \mathrm{~kg} / \mathrm{m}^{3}\right)$ and oats $\left(482.80 \mathrm{~kg} / \mathrm{m}^{3}\right)$ [24] and for oats $\left(412-576 \mathrm{~kg} / \mathrm{m}^{3}\right)$ [25] compared to emmer wheat varieties under the present study.

3.1.5. True Density. True density of grains is one of the physical properties which affects grain hardness, breakage susceptibility, and milling and drying rates (Chang C.S., 1988). The interaction effect of grain type, growing season, and varieties significantly $(P \leq 0.05)$ affected the true density of emmer wheat. The highest $\left(181 \mathrm{~kg} / \mathrm{m}^{3}\right)$ true density value was observed for dehulled Hydroo variety grown in Meher season. In contrast, the lowest true density value of $54.6 \mathrm{~kg} / \mathrm{m}^{3}$ was observed for hulled Sinana 01 variety grown in Belg season (Table 1). Ünal (2009) reported similar results that the true density of kernel (dehulled) grain of emmer wheat varieties was higher than that of the hulled ones. Higher true densities $\left(995 \mathrm{~kg} / \mathrm{m}^{3}\right)$ were reported for barley [22], spring oat $\left(1314 \mathrm{~kg} / \mathrm{m}^{3}\right)$, and winter oats $\left(1295 \mathrm{~kg} / \mathrm{m}^{3}\right)$ [26] compared to emmer wheat varieties of the present study.

3.1.6. Porosity. Porosity is a physical quality property of the grain [9]. The porosity values of emmer wheat varieties ranged from $39.3 \%$ to $37 \%$ (Table 1). Like other physical properties, the porosity of emmer wheat is significantly $(P \leq 0.05)$ affected by the interaction effect of grain types, growing seasons, and varieties. The highest (39.3\%) porosity value was observed for hulled Hydroo variety grown in Belg season. In contrast, the lowest (37\%) porosity was determined for the hulled Sinana 01 grown in Meher season. The lowest porosity is probably due to the moisture content, because with more moisture the grain volume increases as the number of grains in a fixed volume decreases. There were reports of porosity values of $46.9 \%$ for bread wheat [27], 31.25\% for barley [22], and for oats (59.5-62.5\%) [28]. The emmer wheat's porosity recorded in this study was higher than that of barley but lower than those of wheat and oats.

\subsection{Effect of Growing Season, Grain Types, and Varieties on the Proximate Composition and Ash Content of Emmer Wheat}

3.2.1. Moisture Content. The interaction effect of grain type, growing season, and variety showed a highly significant $(P \leq 0.001)$ effect on the grain moisture content (Table 2$)$. The highest (11\%) moisture content was observed in dehulled local variety grown in Meher season, whereas the 


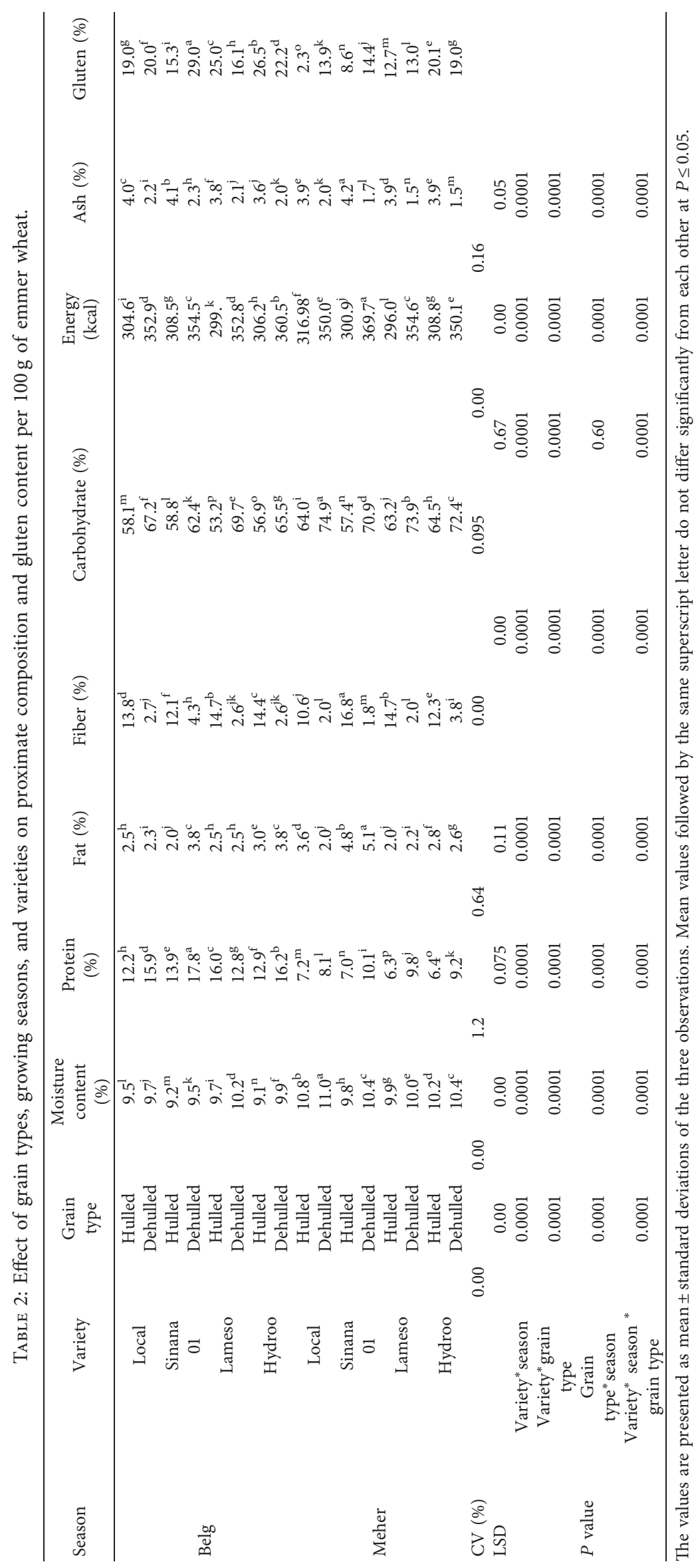


lowest (9.1\%) moisture content was determined in dehulled Hydroo varieties grown in the Belg season. The highest moisture content in samples from the Meher season may be attributed to the heavier rainfall compared to the Belg season. The growing season influences the chemical composition during the seed development. During the development, any change in the proteins or thickness of the seed coat is a result in a difference in moisture content [29]. The storage life of grains is directly influenced by seed moisture content, for long-term storage wheat should be dried quickly to a moisture level of about 12\% [29]. Therefore, in this study, we observed that moisture content of $11 \%$ is safer for storage to maintain the seed quality and viability for prolonged duration.

3.2.2. Protein Content. Proteins are the source of essential amino acids and are concentrated in the aleurone layer, pericarp, and germs of the grain. The crude protein is significantly affected by the interaction effect of growing seasons, grain types, and varieties. The highest protein content $(17.82 \%)$ was observed in dehulled Sinana 01 variety grown in Belg season (Table 2). However, the lowest $(6.33 \%)$ protein content was determined in the hulled Lameso variety grown in Meher season. The dehulled grains showed higher protein content compared to the hulled ones due to the loss of husk. Genotypic factors, grain types, and the environment had significantly influenced the protein content. Lacko-Bartošová and Čurná [30] reported that varieties and growing seasons had a significant influence on the protein content of emmer wheat. The same authors also found that crude protein content in the range of $13.38 \%$ to $14.1 \%$ in emmer wheat and some varieties from the present study recorded higher protein content. Giacintucci et al. [31] compared spring emmer wheat and common wheat quality and reported that emmer wheat recorded a higher (14.4\%) crude protein content than common wheat (11.8\%). Bordoni et al. [32] found that the protein content in durum wheat (13.68\%) is lower than those in some emmer wheat varieties considered in the present study. Sterna et al. [33] also reported that oats contain $9.7 \%$ to $17.30 \%$ protein. The present study clearly demonstrated that some Ethiopian emmer wheat varieties can be considered as a good source of protein with high proportion of essential amino acids.

3.2.3. Fat Content. Fat is a minor constituent in cereals (e.g., $3 \%$ in wheat kernel) but quite complex and is present in both free and bounded forms. The interaction effect of grain type, variety, and growing seasons had significantly impacted the fat content of emmer wheat (Table 2). Dehulled grain of Sinana 01 variety from Meher season has recorded the highest (5.1\%) fat content. In contrast, the lowest (2\%) fat content was observed in the hulled variety grown in Belg season. The difference in fat content among grain types (hulled and dehulled) is attributed to the germ or embryo, which is relatively more rich in fat than in the bran. Giacintucci et al. [31] reported that spring emmer wheat has the highest fat content $(2.33 \%)$ compared to winter emmer wheat (1.52\%) which shows the significant effect of growing season on fat content. Contrary to our findings, LackoBartošová and Čurná [30] reported that the growing season has no significant influence on the fat content of emmer wheat. Lower fat content in durum wheat $(2.47 \%)$ by Bordoni et al. [32] and higher fat content in oats $(5.2 \%$ to $12.40 \%$ ) by Sterna et al. [33] were reported compared to some of the emmer wheat varieties considered in the present study. Jocelyne et al. [34] also reported the fat content in wheat $(1.73 \%)$, maize $(4.18 \%)$, sorghum $(3.65 \%)$, and millet (4.58\%).

3.2.4. Crude Fiber Content. In wheat, whole grain flour and bran are reliable sources of fiber which has health benefits and positively contributes to prevention of heart diseases and diabetes, reduces risk of obesity and some types of cancer, and improves both short-term and long-term memory functions [33]. The interaction effect of grain types, variety, and growing season has highly significant $(P \leq 0.01)$ effect on the crude fiber and ash content of emmer wheat. Hulled Sinana 01 variety grown in Meher season recorded the highest $(16.78 \%)$ crude fiber, whereas the lowest (1.8\%) was in dehulled variety from the same season (Table 2). Contrary to our findings, Lacko-Bartošová and Čurná [30] reported that varieties and growing seasons did not show any significant influence on the fiber content of emmer wheat.

Different researchers have reported that wheat bran is rich in soluble fiber and is known to possess healthpromoting properties [35]. About 34 to $63 \%$ of the wheat bran is occupied by the rich stock of soluble and insoluble dietary fiber [35]. Several studies found high total fiber content compared to some of the emmer wheat varieties in our study in wheat $(13.1 \%)$ and oats $(10,6 \%)$ by USDA [36]; in oats (13.66-30.17\%) by Sterna et al. [33]; and in wheat $(2.18 \%)$, maize $(6.69 \%)$, sorghum $(8.14 \%)$, and millet $(3.89 \%)$ by [34].

3.2.5. Ash Content. Significant differences $(P \leq 0.01)$ have been observed between growing season, grain types, and varieties (Table 2). Sinana 01 variety grown in Meher season with hulled grain type had recorded the highest $(4.2 \%)$ ash content, whereas the lowest (1.5\%) was determined in dehulled Lameso variety grown in Meher season (Table 2). Similarly, earlier reports showed differences in ash content among different emmer $(0.85 \%$ and $2.46 \%)$ varieties [3] and significant effect of growing season on ash content [31]. Biel et al. [37] reported that the ash content in common wheat grains and triticale is $1.82 \%$ and $1.3 \%$, respectively, which is lower than emmer wheat varieties studied. Jocelyne et al. [34] also reported that the ash contents of wheat, maize, sorghum, and millet were $1.41 \%, 1.79 \%, 4.16 \%$, and $2.16 \%$, respectively.

3.2.6. Carbohydrates Content. There was highly significant $(P \leq 0.01)$ interaction effect of grain types, growing seasons, 


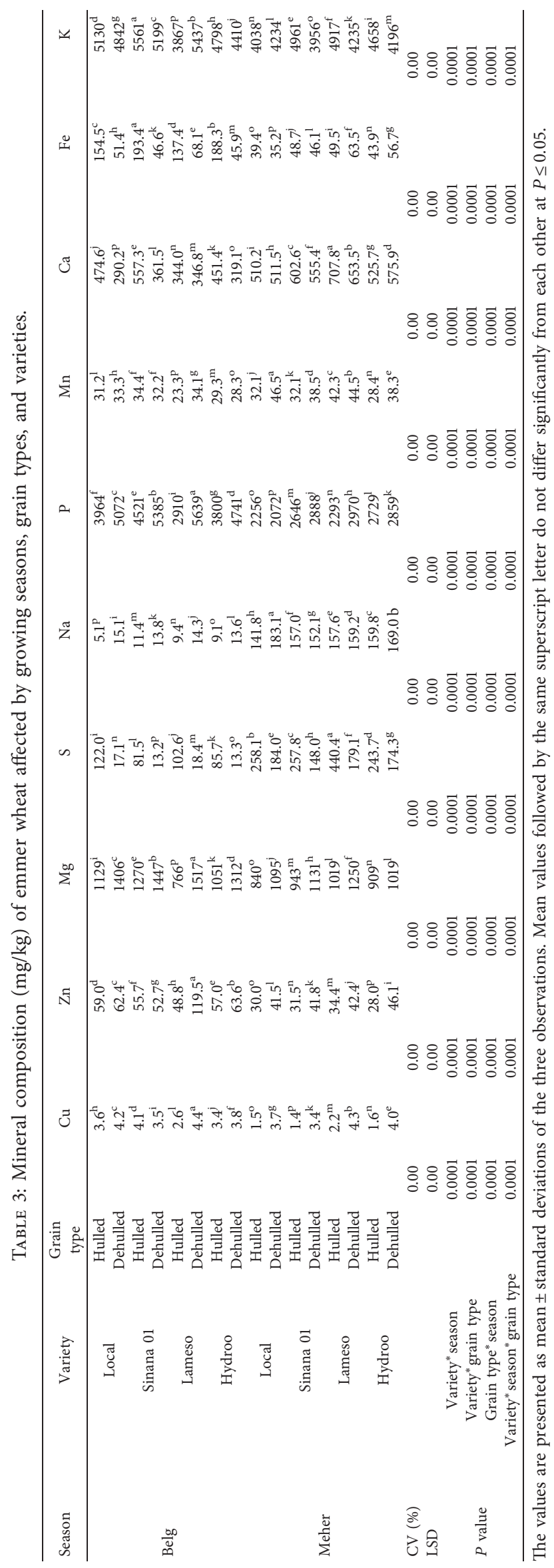


and varieties on carbohydrate content of emmer wheat (Table 2). The highest (74.9\%) carbohydrate content was in dehulled local cultivar grown in Meher season. However, the lowest (53.2\%) carbohydrate content was in the hulled Lameso variety from Belg season. In a previous study, Dhanavath and Rao [3] found a higher carbohydrate content of emmer wheat (78\% to $83 \%$ ) compared to the present study and concluded that varietal differences and environmental conditions influence the protein, carbohydrate, fat, ash, and fiber content of emmer wheat. It was also found that rainfall during the different stages of wheat growth (vegetative and ripening) influences the carbohydrate content in the wheat grains (Jocelyne et al. [34]).

3.2.7. Gross Energy. The ANOVA revealed that interaction effects of grain types, growing seasons, and varieties had highly significant $(P \leq 0.01)$ effect on energy content of emmer wheat and ranged from $296 \mathrm{kcal} / 100 \mathrm{~g}$ to $369.7 \mathrm{kcal} /$ $100 \mathrm{~g}$ (Table 2). The highest $(369.7 \mathrm{kcal} / 100 \mathrm{~g})$ energy content was observed in dehulled Sinana 01 variety from the Meher season, whereas the lowest $(296 \mathrm{kcal} / 100 \mathrm{~g})$ energy was by the hulled Lameso variety from the same season. The variation in the energy values among the studied varieties was attributed to the variations in the composition of fat, carbohydrates, and proteins among the varieties and dehulled and hulled samples. According to Jocelyne et al. [34], the energy values in wheat, maize, sorghum, and millets were $308.22 \mathrm{kcal} / 100 \mathrm{~g}, 321.79 \mathrm{kcal} / 100 \mathrm{~g}, 308.84 \mathrm{kcal} / 100 \mathrm{~g}$, and $319.39 \mathrm{kcal} / 100 \mathrm{~g}$, respectively, which are lower than the energy values of emmer wheat varieties considered in the present study. Bordoni et al. [32] also reported that the energy value of durum wheat is $339 \mathrm{kcal} / 100 \mathrm{~g}$, which is higher than those of some emmer wheat varieties.

3.2.8. Gluten Content. Gluten content is an important quality component, which directly depends on grain protein content. Gluten content is also significantly $(P \leq 0.01)$ influenced by the interaction effect of growing seasons, grain types, and varieties (Table 2). The dehulled Sinana 01 variety from Belg season recorded the highest (29.02\%) gluten content, whereas the lowest $(2.20 \%)$ gluten content was recorded in the hulled local landrace from Meher season. Konvalina [38] reported that the mean gluten content of emmer wheat varieties ranged from $1.7 \%$ to $11 \%$, which is comparable to our results. Zecevic et al. [39] concluded that the gluten content of wheat was significantly affected by genetics, growing season, crop management, and their interactions. Rohi et al. [1] also reported that the major factors responsible for the protein content in wheat grains are varieties and growing seasons.

\subsection{Mineral Composition of Emmer Wheat. The ANOVA} analysis revealed that interaction effect of growing season, grain types, and variety showed highly significant $(P \leq 0.01)$ effect on the mineral composition of emmer wheat. The results of 10 mineral (calcium, sulphur, copper, magnesium, sodium, iron, zinc, manganese, potassium, and phosphorus) compositions of emmer wheat are presented and discussed in the following section.

High concentrations of phosphorus $(5639 \mathrm{mg} / \mathrm{kg}$ ), copper $(4.4 \mathrm{mg} / \mathrm{kg})$, zinc $(119.5 \mathrm{mg} / \mathrm{kg})$, magnesium $(1517 \mathrm{mg} / \mathrm{kg})$, sulphur $(440.4 \mathrm{mg} / \mathrm{kg})$, and calcium $(707.8 \mathrm{mg} / \mathrm{kg}$ ) were found in dehulled Lameso variety from Belg season (Table 3). However, the same variety (Lameso) reported lower quantities of potassium $(3867 \mathrm{mg} / \mathrm{kg})$ and magnesium $(766 \mathrm{mg} / \mathrm{kg})$ in the hulled grains from the same growing season. The highest iron $(193.4 \mathrm{mg} / \mathrm{kg}$ ) and potassium $(5561 \mathrm{mg} / \mathrm{kg}$ ) concentrations were observed in hulled Sinana 01 variety from Belg season (Table 3). Sodium $(183 \mathrm{mg} / \mathrm{kg})$ and manganese $(46.5 \mathrm{mg} / \mathrm{kg})$ were observed to be the highest in dehulled local variety from Meher season.

The study showed the highest concentration of calcium $(707.8 \mathrm{mg} / \mathrm{kg})$ in dehulled Lameso variety from Belg season, which is higher than the result reported for wheat $(33 \mathrm{mg} / \mathrm{kg})$ by USDA [36]. Piergiovanni et al. [40] also showed higher concentration of calcium in emmer wheat $(42.2 \mathrm{mg} / \mathrm{kg})$ than wheat $(35 \mathrm{mg} / \mathrm{kg})$. Moreover, Biel et al. [37] also reported lower calcium concentrations reported in oats $(13.1 \mathrm{mg} / \mathrm{kg})$, wheat $(3.7 \mathrm{mg} / \mathrm{kg})$, and barley $(4 \mathrm{mg} / \mathrm{kg})$ compared to the present study. Therefore, the results of our study demonstrated that emmer wheat can be considered as a good source of calcium than wheat and oats.

Wide ranges of iron content $(35.2 \mathrm{mg} / \mathrm{kg}$ to $193.4 \mathrm{mg} / \mathrm{kg}$ ) and zinc concentration $(28 \mathrm{mg} / \mathrm{kg}$ to $119.5 \mathrm{mg} / \mathrm{kg})$ were found in emmer wheat varieties (Table 3). Zhao et al. [41] reported a lower concentration of iron $(34.1 \mathrm{mg} / \mathrm{kg})$ in our study but higher concentration of zinc $(22.8 \mathrm{mg} / \mathrm{kg})$ in emmer wheat compared to wheat $(2.96 \mathrm{mg} / \mathrm{kg})$ reported by USDA [36]. Similarly, Rubene and Kuka [42] reported lower iron content of oats $(120.4 \mathrm{mg} / \mathrm{kg})$ and wheat $(52.81 \mathrm{mg} / \mathrm{kg})$ than some of the emmer wheat varieties considered in this study.

Ethiopian emmer wheat varieties were found to be very nutritious loaded with high essential minerals like calcium $(707.8 \mathrm{mg} / \mathrm{kg})$, zinc $(119.5 \mathrm{mg} / \mathrm{kg})$, and iron $(193.4 \mathrm{mg} / \mathrm{kg})$ wheat compared to emmer wheat grown in other parts of the world. Moreover, emmer wheat contains higher concentrations of zinc, iron, phosphorus, magnesium, and copper than wheat $[20,43]$ and can be can be used to alleviate calcium, zinc, and iron deficiency in humans where approximately 1.5 billion people worldwide are facing iron and zinc deficiencies [37].

The concentration of phosphorus in emmer wheat ranges from $2072 \mathrm{mg} / \mathrm{kg}$ to $5639 \mathrm{mg} / \mathrm{kg}$ (Table 3). Hejcman and Hejcmanová [20] reported that the phosphorus concentration in wheat was $3600 \mathrm{mg} / \mathrm{kg}$, which is lower than some emmer wheat varieties of the present study.

The ANOVA revealed that the sodium amount varied from $5.1 \mathrm{mg} / \mathrm{kg}$ to $183 \mathrm{mg} / \mathrm{kg}$ (Table 3). Rubene and Kuka [42] reported sodium content in oats $(55.52 \mathrm{mg} / \mathrm{kg})$ and in wheat $(48.6 \mathrm{mg} / \mathrm{kg})$, which was lower than those of some of the emmer wheat varieties used in our study. Likewise, Jocelyne et al. [34] also reported lower sodium content in wheat, maize, sorghum, and millet.

Sulphur is the fourth most abundant macro element in crops, a component of amino acids (Methionine and 
Cysteine), and its deficiency leads to amino acid cysteine deficiency. The sulphur concentration of emmer wheat varieties ranges from $13.2 \mathrm{mg} / \mathrm{kg}$ to $440.4 \mathrm{mg} / \mathrm{kg}$, which is higher than the average sulphur content in oats grains $(2.03 \mathrm{mg} / \mathrm{kg})$ reported by Rubene and Kuka [42].

Our study found that some of the Ethiopian emmer wheat varieties can be a good source of iron, zinc, calcium, sulphur, sodium, and phosphorus and can fulfil the recommended daily allowance providing a major part of daily mineral requirements of $\mathrm{Fe}$ and $\mathrm{Zn}$ for people with specific mineral deficiency.

The probable variation in mineral concentration in different varieties may be due to the amounts of minerals transported by roots during grain development and the amount distributed to the grain by vegetative tissue through the phloem. Photosynthetic capacity of vegetative tissue is found to be an important factor in determining the grain mineral concentration [44].

The mineral contents were strongly affected by weather condition, especially by precipitation and temperature. The emmer wheat varieties from Belg season showed the highest concentration for most of the minerals. Zhao et al. [41] found that the mineral composition of water gained from the weather has a significant effect on the mineral compositions of the grains. Hejcman and Hejcmanová [20] reported that the minerals (iron, phosphorus, nitrogen, zinc, and copper) concentrations in hulled emmer wheat are too low as compared to those of dehulled grains.

3.4. Bioavailability of $\mathrm{Fe}, \mathrm{Ca}$, and $\mathrm{Zn}$ in Emmer Wheat. Bioavailability is a complex interaction between plant phosphorus $(\mathrm{P})$ uptake and storage in grain (as phytate), and plant micronutrient uptake refers to the fraction of minerals utilized by the human body out of the total undigested amount [45].

3.4.1. Bioavailability of Iron. The ANOVA showed that interaction of grain types, varieties, and growing seasons had highly $(P \leq 0.01)$ significant effect on the bioavailability value of iron in emmer wheat with a range from 0.46 to 0.0325 (Table 4). The highest ratio of phytate: Fe concentration was in dehulled local landrace grown in Meher season, whereas the lowest (0.03) was in hulled Hydroo variety from Belg season. The phytate: Fe molar ratio should be $<1.0$ and preferably $<0.4$ is favourable for iron bioabsorption [46]. The emmer wheat varieties can be considered for good iron bioavailability.

3.4.2. Bioavailability of Zinc. The interaction effect of grain types, varieties, and growing seasons had highly $(P \leq 0.01)$ significant impact on zinc bioavailability. The phytate: zinc molar ratio of emmer wheat ranged from 0.6 to 0.05 (Table 4). There was a wide variation in phytate: zinc molar ratio between emmer wheat varieties grown in different seasons. The highest (0.6) zinc bioavailability was reported by hulled local landrace from Meher season. In contrast, the hulled Lameso variety from Belg season had the lowest (0.05)
TABLE 4: Bioavailability of iron, zinc, and calcium in emmer wheat grains as affected by grain types, growing seasons, and varieties.

\begin{tabular}{|c|c|c|c|c|c|}
\hline Season & Variety & $\begin{array}{l}\text { Grain } \\
\text { type }\end{array}$ & $\begin{array}{c}\text { PA: } \\
\mathrm{Fe}\end{array}$ & $\begin{array}{c}\mathrm{PA}: \\
\mathrm{Zn}\end{array}$ & $\begin{array}{r}\text { PA: } \\
\mathrm{Ca}\end{array}$ \\
\hline \multirow{8}{*}{ Belg } & \multirow[b]{2}{*}{ Local } & Hulled & $0.09^{\text {gh }}$ & $0.26^{\text {efg }}$ & $0.02^{\mathrm{de}}$ \\
\hline & & Dehulled & $0.29^{c}$ & $0.29^{\mathrm{de}}$ & $0.04^{\mathrm{c}}$ \\
\hline & \multirow{2}{*}{ Sinana 01} & Hulled & $0.04^{\mathrm{ij}}$ & $0.19^{\text {gh }}$ & $0.01^{\text {gh }}$ \\
\hline & & Dehulled & $0.23^{\mathrm{d}}$ & $0.24^{\mathrm{efg}}$ & $0.02^{\mathrm{e}}$ \\
\hline & \multirow{2}{*}{ Lameso } & Hulled & $0.07^{\text {hi }}$ & $0.05^{j}$ & $0.02^{\mathrm{de}}$ \\
\hline & & Dehulled & $0.08^{\mathrm{gh}}$ & $0.30 \mathrm{~d}$ & $0.01^{\text {gh }}$ \\
\hline & \multirow{2}{*}{ Hydroo } & Hulled & $0.03^{j}$ & $0.11^{\mathrm{i}}$ & $0.01^{\mathrm{hi}}$ \\
\hline & & Dehulled & $0.38^{\mathrm{b}}$ & $0.03^{j}$ & $0.21^{\mathrm{b}}$ \\
\hline \multirow{8}{*}{ Meher } & \multirow{2}{*}{ Local } & Hulled & $0.39^{\mathrm{b}}$ & $0.60^{\mathrm{a}}$ & $0.02^{\mathrm{e}}$ \\
\hline & & Dehulled & $0.46^{\mathrm{a}}$ & $0.44^{\mathrm{b}}$ & $0.02^{\mathrm{d}}$ \\
\hline & \multirow{2}{*}{ Sinana 01} & Hulled & $0.20^{\mathrm{e}}$ & $0.35^{\mathrm{c}}$ & $0.01^{\mathrm{fg}}$ \\
\hline & & Dehulled & $0.23^{\mathrm{d}}$ & $0.31^{\mathrm{cd}}$ & $0.01^{\mathrm{f}}$ \\
\hline & \multirow{2}{*}{ Lameso } & Hulled & $0.18^{\mathrm{ef}}$ & $0.29^{\mathrm{de}}$ & $0.01^{\mathrm{ij}}$ \\
\hline & & Dehulled & $0.11^{\mathrm{g}}$ & $0.19^{\mathrm{h}}$ & $0.01^{\mathrm{j}}$ \\
\hline & \multirow{2}{*}{ Hydroo } & Hulled & $0.16^{\mathrm{f}}$ & $0.31^{\mathrm{d}}$ & $0.01^{\text {hi }}$ \\
\hline & & Dehulled & $0.29^{c}$ & $0.43^{\mathrm{b}}$ & $0.21^{\mathrm{a}}$ \\
\hline $\begin{array}{l}\mathrm{CV} \\
(\%)\end{array}$ & & & 6.8 & 8 & 2.2 \\
\hline LSD & & & & & \\
\hline \multirow{4}{*}{$\begin{array}{l}P \\
\text { value }\end{array}$} & Variety* season & & 0.0001 & 0.0001 & 0.0001 \\
\hline & Variety $^{*}$ grain type & & 0.0001 & 0.0001 & 0.0001 \\
\hline & Grain type* season & & 0.0001 & 0.8 & 0.03 \\
\hline & $\begin{array}{c}\text { Variety* season* grain } \\
\text { type }\end{array}$ & & 0.006 & 0.0001 & 0.0001 \\
\hline
\end{tabular}

PA: phytic acid. The values are presented as mean \pm standard deviations of the three observations. Mean values followed by the same superscript letter do not differ significantly from each other at $P \leq 0.05$.

bioavailability of zinc. The phytate: zinc ratio $<15$ is desirable for zinc absorption and most of emmer wheat varieties grown in different seasons showed a phytate: zinc ratio $<15$ which makes them desirable. Hussain et al. [47] reported a wide variation in grain phytate : zinc molar ratio concentration (24 to 41 ) in wheat varieties, making wheat undesirable as the source of zinc.

3.4.3. Bioavailability of Calcium. The ANOVA revealed highly $(P \leq 0.01)$ significant interaction effects of grain types, varieties, and growing seasons on the phytate:calcium molar ratio which ranged from 0.21 to 0.0085 (Table 4). Dehulled grain of Hydroo variety grown in Meher season had recorded the highest $(0.21)$ molar ratio, whereas the lowest $(0.0085)$ was recorded by the hulled Sinana 01 variety grown in Meher season. Calcium absorption can be impaired by a phytate to calcium molar ratio above 0.17 [48]. Therefore, the bioavailability of calcium for Hydroo variety is lower because the molar ratio is higher than the critical value. Castro-Alba et al. [49] reported low bioavailability of calcium in cereals (0.61 to 12.2) including oats (4.00), where the molar ratios are higher than the critical value.

3.5. Amino Acid Composition. Amino acids are the major structural, functional components and building blocks of proteins. Amino acids are required by the body to regulate the growth, repair, maintenance, and replacement of tissue 
[50]. During our study, the aspartic acid, arginine, glutamic acid, isoleucine, leucine, valine, lysine, methionine, phenylalanine, proline, threonine, and tyrosine quantities of emmer wheat were determined. The main and interaction effect of grain types, growing seasons, and varieties was significantly $(P \leq 0.01)$ affected by the amino acid composition of emmer wheat (Table 5).

The highest concentrations of aspartic acid $(2.78 \mathrm{~g} / 100 \mathrm{~g})$, arginine $(1.68 \mathrm{~g} / 100 \mathrm{~g})$, threonine $(1.39 \mathrm{~g} / 100 \mathrm{~g})$, proline $(9.42 \mathrm{~g} / 100 \mathrm{~g})$, and isoleucine $(10.90 \mathrm{~g} / 100 \mathrm{~g})$ were observed in hulled Sinana 01 variety from Belg season. In contract, the lowest aspartic acid $(1.77 \mathrm{~g} / 100 \mathrm{~g})$, arginine $(0.43 \mathrm{~g} / 100 \mathrm{~g})$, threonine $(0.18 \mathrm{~g} / 100 \mathrm{~g})$, proline $(0.7 \mathrm{~g} / 100 \mathrm{~g})$, and isoleucine $(0.86 \mathrm{~g} / 100 \mathrm{~g})$ concentrations were recorded in local landrace (dehulled for aspartic acid and hulled for arginine), Lameso (dehulled), Hydroo (hulled), and Sinana 01 (dehulled) varieties, respectively (Table 5). The variation in amino acid composition was attributed to the differences in the genetic makeup of wheat types (soft, medium, and hard) and varieties [50].

Similarly, Zafar et al. [50] reported that wheat varieties showed variation in amino acid composition due to the genetic makeup and environmental conditions. In Meher season, the highest concentrations of glutamic acid $(5.27 \mathrm{~g} /$ $100 \mathrm{~g})$, leucine $(11.23 \mathrm{~g} / 100 \mathrm{~g})$, phenylalanine $(18.46 \mathrm{~g} / 100 \mathrm{~g})$, tyrosine $(2.59 \mathrm{~g} / 100 \mathrm{~g})$, valine $(7.37 \mathrm{~g} / 100 \mathrm{~g})$, and methionine $(2.05 \mathrm{~g} / 100 \mathrm{~g})$ were determined in hulled Hydroo variety. The highest $(2.37 \mathrm{~g} / 100 \mathrm{~g})$ lysine content was determined in the dehulled Hydroo variety from Belg season, whereas the lowest concentrations for the amino acids mentioned above were in the dehulled Hydroo varieties from Belg season (Table 4).

From a nutritional point of view, lysine, threonine, and leucine rank first and second among the most limiting amino acids in cereal grains. Our studies found a wide range of lysine content $(1.58 \mathrm{~g} / 100 \mathrm{~g}$ to $2.37 \mathrm{~g} / 100 \mathrm{~g})$, threonine content $(0.18 \mathrm{~g} / 100 \mathrm{~g}$ to $1.42 \mathrm{~g} / 100 \mathrm{~g})$, and leucine content $(1.61 \mathrm{~g} /$ $100 \mathrm{~g}$ to $11.23 \mathrm{~g} / 100 \mathrm{~g}$ ) in the emmer wheat varieties studied (Table 5). Compared to our study, higher lysine contents $(1.72 \mathrm{~g} / 100 \mathrm{~g}$ to $2.89 \mathrm{~g} / 100 \mathrm{~g})$ for emmer wheat [51] and for triticale $(3.69 \mathrm{~g} / 100 \mathrm{~g})$ [52] were reported earlier. Similarly, the leucine content of emmer wheat varieties under study recorded higher leucine content than that in the report of Konvalina and Stehno [51] for emmer wheat varieties $(4.23 \mathrm{~g} / 100 \mathrm{~g}$ to $6.02 \mathrm{~g} / 100 \mathrm{~g})$. However, the threonine content in emmer wheat varieties found in our study (Table 5) is lower than those of emmer wheat varieties $(1.77 \mathrm{~g} / 100 \mathrm{~g}$ to $2.77 \mathrm{~g} / 100 \mathrm{~g}$ ) reported by Konvalina and Stehno [51] and triticale $(3.68 \mathrm{~g} / 100 \mathrm{~g})$ reported by [52]. Similarly, contents of glutamic acid $(3.2 \mathrm{~g} / 100 \mathrm{~g}$ to $5.27 \mathrm{~g} / 100 \mathrm{~g})$ recorded for emmer wheat varieties in our study (Table 5) were lower compared to the glutamic acid content of wheat $(1.292 \mathrm{~g} /$ $100 \mathrm{~g})$ reported by Zafar et al. [50].

The essential amino acids such as leucine $(11.23 \mathrm{~g} / 100 \mathrm{~g})$, phenylalanine $(18.46 \mathrm{~g} / 100 \mathrm{~g})$, methionine $(2.05 \mathrm{~g} / 100 \mathrm{~g})$, valine $(7.37 \mathrm{~g} / 100 \mathrm{~g})$, and isoleucine $(10.90 \mathrm{~g} / 100 \mathrm{~g})$ are in higher concentrations in emmer wheat than in wheat varieties (Jiang et al., 2008). Some of the Ethiopian emmer wheat varieties can be characterized with higher protein content than wheat varieties and this is directly related to the higher amino acids. Therefore, some selected emmer wheat varieties from Ethiopia are suitable to formulate special nutritional diets for targeted protein deficient populations.

Most of the amino acids with the highest concentrations were observed in hulled varieties grown in Meher season. Differences in amino acid contents are attributed to the interactions among genetic makeup, growing seasons, and cultural practices. Likewise, previous studies showed that weather conditions had the highest impact on lysine and isoleucine contents among 15 winter wheat varieties [52] and variation in the concentration of all 16 amino acids tested among 7 winter triticale varieties [53].

3.6. Vitamins (B Complex) Compositions. The ANOVA revealed that the interaction of varieties, growing seasons, and grain types had highly significant $(P \leq 0.01)$ influence on vitamin B complex of emmer wheat. Vitamins B9 and E were not detected considering the minimum detection levels of $0.04 \mathrm{mg} / \mathrm{g}$ and $0.1 \mathrm{mg} / \mathrm{g}$, respectively. The highest vitamin B1 $(0.17 \mathrm{mg} / \mathrm{g})$ content was observed in Lameso variety, whereas the highest vitamin B2 $(0.35 \mathrm{mg} / \mathrm{g})$ and vitamin B6 $(5.52 \mathrm{mg} /$ g) contents were observed in hulled Sinana 01 from Meher season (Table 6). The highest vitamin B3 $(10.59 \mathrm{mg} / \mathrm{g})$ content was determined in dehulled Lameso from Belg season. The highest record for vitamin B content was found in hulled samples because more than $80 \%$ of thiamine and pyridoxine are located in the bran or grain outer layers. Variety and growing seasons strongly affected vitamin B content in wheat [1]. Piironen [54] reported that wheat grain constituted thiamine $(2.2$ to $6.3 \mathrm{mg} / \mathrm{g})$, riboflavin $(0.8$ to $2.2 \mathrm{mg} / \mathrm{g}$ ), and niacin $(1.3$ to $7.5 \mathrm{mg} / \mathrm{g})$ and the niacin content is found to be lower than emmer wheat in the present study. Rohi et al. [1] have reported thiamine $(4.6 \mathrm{mg} / \mathrm{g}$ to $6.6 \mathrm{mg} / \mathrm{g})$, riboflavin $(1.84$ to $2.39 \mathrm{mg} / \mathrm{g})$, niacin $(58.09 \mathrm{mg} / \mathrm{g}$ to $63.10 \mathrm{mg} / \mathrm{g})$, and pyridoxine $(6.02 \mathrm{mg} / \mathrm{g}$ to $7.54 \mathrm{mg} / \mathrm{g})$ in whole-wheat flour.

3.7. Antinutritional Factors in Emmer Wheat. In this section, the tannin and phytate contents quantified from emmer wheat grains are presented and discussed below.

3.7.1. Tannin. The three-way interaction of grain types, varieties, and growing seasons had a highly $(P \leq 0.01)$ significant effect on tannin concentrations (Table 6). The tannin concentration of emmer wheat varied from $0.46 \mu \mathrm{g} / \mathrm{g}$ to $0.115 \mu \mathrm{g} / \mathrm{g}$ with the highest $(0.46 \mu \mathrm{g} / \mathrm{g})$ tannin concentrations found in the hulled local landrace grown in Meher season and the lowest $(0.115 \mu \mathrm{g} / \mathrm{g})$ contents are observed in dehulled local landrace in Belg season. Dykes and Rooney [55] reported tannin levels in barley $(0.74 \mathrm{mg} / \mathrm{g})$ and sorghum $(88-21.97 \mathrm{mg} / \mathrm{g})$. Jocelyne et al. [34] also reported higher tannin content in wheat, maize, sorghum, and millet compared to the emmer wheat samples in our study.

3.7.2. Phytate. Grain types, varieties, and growing seasons had highly significant $(P \leq 0.01)$ effect on phytate concentration of emmer wheat (Table 7). The phytic acid 


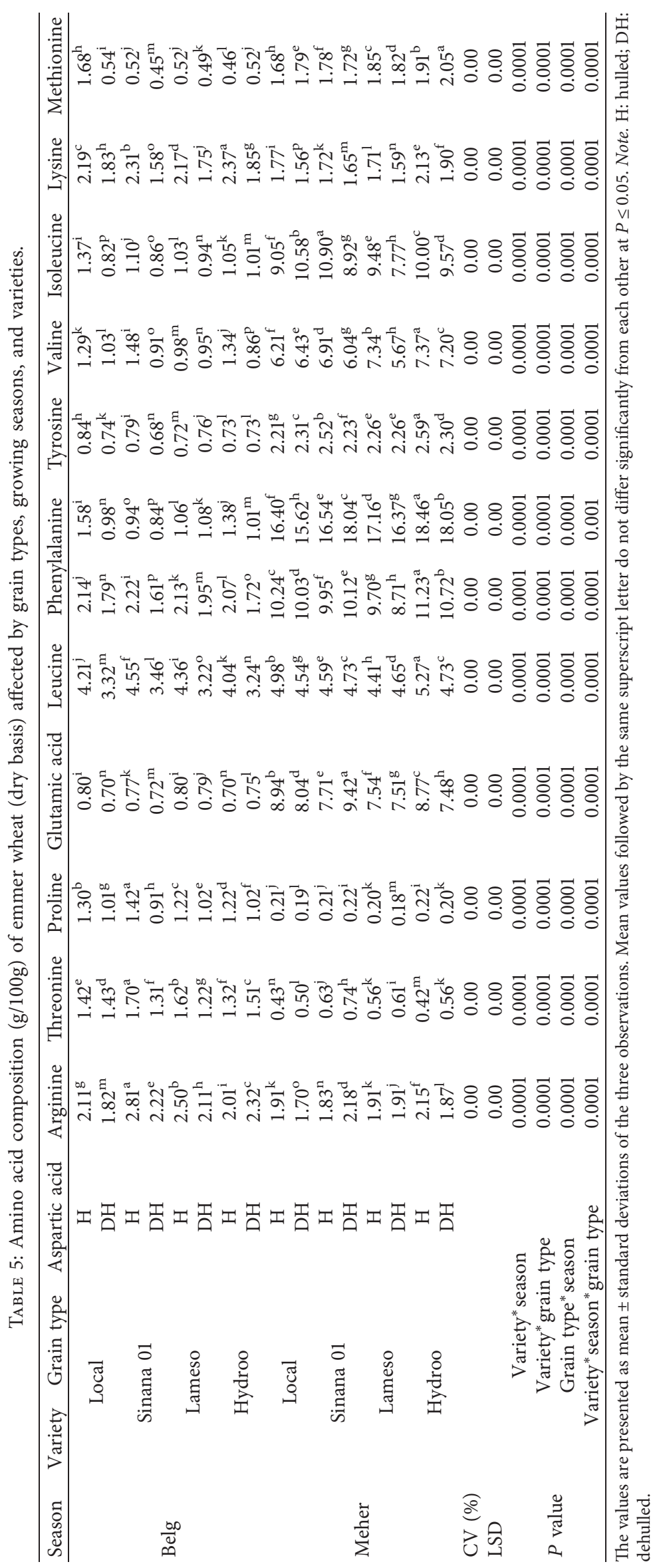


TABLE 6: Vitamin B (mg/g) complex of emmer wheat as affected by growing season, grain types, and variety.

\begin{tabular}{|c|c|c|c|c|c|c|}
\hline Season & Variety & Grain type & Vitamin B1 & Vitamin B2 & Vitamin B3 & Vitamin B6 \\
\hline \multirow{8}{*}{ Belg } & \multirow{2}{*}{ Local } & Hulled & $0.05^{\mathrm{i}}$ & $0.01^{\mathrm{k}}$ & $0.01^{\mathrm{m}}$ & $0.01^{1}$ \\
\hline & & Dehulled & $0.14^{\mathrm{f}}$ & $0.31^{\mathrm{d}}$ & $9.60^{c}$ & $0.36^{\mathrm{k}}$ \\
\hline & \multirow{2}{*}{ Sinana 01} & Hulled & $0.05^{\mathrm{i}}$ & $0.01^{\mathrm{k}}$ & $0.01^{\mathrm{m}}$ & $0.36^{\mathrm{k}}$ \\
\hline & & Dehulled & $0.16^{\mathrm{b}}$ & $0.32^{\mathrm{c}}$ & $9.30^{\mathrm{e}}$ & $0.47^{\mathrm{g}}$ \\
\hline & \multirow{2}{*}{ Lameso } & Hulled & $0.05^{\mathrm{i}}$ & $0.01^{\mathrm{k}}$ & $0.01^{\mathrm{m}}$ & $0.01^{1}$ \\
\hline & & Dehulled & $0.16^{\mathrm{b}}$ & $0.33^{\mathrm{b}}$ & $10.59^{\mathrm{a}}$ & $0.46^{\mathrm{h}}$ \\
\hline & \multirow{2}{*}{ Hydroo } & Hulled & $0.05^{\mathrm{i}}$ & $0.01^{\mathrm{k}}$ & $0.01^{\mathrm{m}}$ & $0.01^{1}$ \\
\hline & & Dehulled & $0.13^{\mathrm{g}}$ & $0.30^{\mathrm{e}}$ & $10.04^{\mathrm{b}}$ & $0.50^{\mathrm{e}}$ \\
\hline \multirow{8}{*}{ Meher } & \multirow{2}{*}{ Local } & Hulled & $0.15^{\mathrm{c}}$ & $0.19^{\mathrm{i}}$ & $9.52^{\mathrm{d}}$ & $0.39^{j}$ \\
\hline & & Dehulled & $0.15^{\mathrm{d}}$ & $0.21^{\mathrm{h}}$ & $8.88^{\mathrm{f}}$ & $0.66^{\mathrm{b}}$ \\
\hline & \multirow{2}{*}{ Sinana 01} & Hulled & $0.13^{\mathrm{g}}$ & $0.35^{\mathrm{a}}$ & $5.21^{\mathrm{k}}$ & $5.52^{\mathrm{a}}$ \\
\hline & & Dehulled & $0.13^{\mathrm{g}}$ & $0.18^{j}$ & $4.68^{1}$ & $0.46^{\mathrm{h}}$ \\
\hline & \multirow{2}{*}{ Lameso } & Hulled & $0.17^{\mathrm{a}}$ & $0.21^{\mathrm{h}}$ & $7.85^{\mathrm{i}}$ & $0.44^{\mathrm{i}}$ \\
\hline & & Dehulled & $0.15^{\mathrm{d}}$ & $0.18^{j}$ & $7.66^{\mathrm{j}}$ & $0.59^{c}$ \\
\hline & \multirow{2}{*}{ Hydroo } & Hulled & $0.15^{\mathrm{e}}$ & $0.25^{\mathrm{g}}$ & $8.00^{\mathrm{g}}$ & $0.48^{\mathrm{f}}$ \\
\hline & & Dehulled & $0.12^{\mathrm{h}}$ & $0.27^{\mathrm{f}}$ & $7.94^{\mathrm{h}}$ & $0.52^{\mathrm{d}}$ \\
\hline CV (\%) & & & 0.00 & 0.00 & 0.00 & 0.00 \\
\hline \multirow[t]{2}{*}{ LSD } & \multirow{2}{*}{\multicolumn{2}{|c|}{ Variety* season }} & 0.00 & 0.00 & 0.00 & 0.00 \\
\hline & & & 0.0001 & 0.0001 & 0.0001 & 0.0001 \\
\hline \multirow{3}{*}{$P$ value } & \multicolumn{2}{|c|}{ Variety $^{*}$ grain type } & 0.0001 & 0.0001 & 0.0001 & 0.0001 \\
\hline & \multicolumn{2}{|c|}{ Grain type* season } & 0.0001 & 0.0001 & 0.0001 & 0.0001 \\
\hline & \multicolumn{2}{|c|}{ Variety* season* grain type } & 0.0001 & 0.0001 & 0.0001 & 0.0001 \\
\hline
\end{tabular}

The values are presented as mean \pm standard deviations of the three observations. Mean values followed by the same superscript letter do not differ significantly from each other at $P \leq 0.05$.

TABLE 7: Antinutritional factors (phytate and tannin) and antioxidant properties of emmer wheat affected by variety, growing season, and grain types.

\begin{tabular}{|c|c|c|c|c|c|}
\hline Season & Variety & Grain type & Phytate $(\mu \mathrm{g} / \mathrm{g})$ & Tannin $(\mu \mathrm{g} / \mathrm{g})$ & Antioxidant (mg Trolox/kg) \\
\hline \multirow{8}{*}{ Belg } & \multirow{2}{*}{ Local } & Hulled & $0.16^{\mathrm{b}}$ & $0.35^{\mathrm{b}}$ & $16.50^{\mathrm{a}}$ \\
\hline & & Dehulled & $0.14^{\mathrm{c}}$ & $0.12^{\text {cde }}$ & $10.65^{\mathrm{bc}}$ \\
\hline & \multirow{2}{*}{ Sinana 01} & Hulled & $0.11 \mathrm{~d}^{\mathrm{e}}$ & $0.11^{\text {cde }}$ & $9.45^{\mathrm{cd}}$ \\
\hline & & Dehulled & $0.14^{\mathrm{c}}$ & $0.14^{\mathrm{cd}}$ & $8.85^{\text {cde }}$ \\
\hline & \multirow{2}{*}{ Lameso } & Hulled & $0.12^{\mathrm{cd}}$ & $0.17^{\mathrm{c}}$ & $7.41 \mathrm{~d}^{\mathrm{ef}}$ \\
\hline & & Dehulled & $0.05^{\mathrm{g}}$ & $0.15^{\mathrm{c}}$ & $9.85^{\mathrm{bc}}$ \\
\hline & \multirow{2}{*}{ Hydroo } & Hulled & $0.18^{\mathrm{b}}$ & $0.17^{\mathrm{c}}$ & $11.79^{\mathrm{b}}$ \\
\hline & & Dehulled & $0.13^{\mathrm{cd}}$ & $0.12^{\text {cde }}$ & $6.68^{\text {efg }}$ \\
\hline \multirow{8}{*}{ Meher } & \multirow{2}{*}{ Local } & Hulled & $0.17^{\mathrm{b}}$ & $0.46^{\mathrm{a}}$ & $17.38^{\mathrm{a}}$ \\
\hline & & Dehulled & $0.19^{\mathrm{ab}}$ & $0.15^{\mathrm{c}}$ & $10.23^{\mathrm{bc}}$ \\
\hline & \multirow{2}{*}{ Sinana 01} & Hulled & $0.12^{\mathrm{cd}}$ & $0.12^{\text {cde }}$ & $6.15^{\mathrm{fg}}$ \\
\hline & & Dehulled & $0.13^{\mathrm{c}}$ & $0.15^{\mathrm{c}}$ & $10.64^{\mathrm{bc}}$ \\
\hline & \multirow{2}{*}{ Lameso } & Hulled & $0.11^{\mathrm{de}}$ & $0.07^{\mathrm{e}}$ & $5.45 \mathrm{f}^{\mathrm{g}}$ \\
\hline & & Dehulled & $0.08^{\mathrm{fg}}$ & $0.14^{\mathrm{c}}$ & $4.63^{\mathrm{g}}$ \\
\hline & \multirow{2}{*}{ Hydroo } & Hulled & $0.09^{\mathrm{ef}}$ & $0.07^{\mathrm{de}}$ & $8.94^{\mathrm{cd}}$ \\
\hline & & Dehulled & $0.21 \mathrm{a}$ & $0.14^{\mathrm{c}}$ & $4.63^{\mathrm{g}}$ \\
\hline $\mathrm{CV}(\%)$ & & & 9 & 17.5 & 11 \\
\hline LSD & & & 0.025 & 0.060 & 2.23 \\
\hline \multirow{4}{*}{$P$ value } & Variety*season & & 0.0982 & 0.0029 & 0.0109 \\
\hline & Variety* grain type & & $<.0001$ & $<.0001$ & $<.0001$ \\
\hline & Grain type* season & & $<.0001$ & 0.0982 & 0.6635 \\
\hline & Variety* season* grain type & & $<.0001$ & 0.0184 & 0.0074 \\
\hline
\end{tabular}

The values are presented as mean \pm standard deviations of the three observations. Mean values followed by the same superscript letter do not differ significantly from each other at $P \leq 0.05$.

concentration varies from $0.208 \mu \mathrm{g} / \mathrm{g}$ to $0.0555 \mu \mathrm{g} / \mathrm{g}$ with the highest $(0.208 \mu \mathrm{g} / \mathrm{g})$ concentration found in dehulled Hydroo variety from Meher season and the lowest $(0.0555 \mu \mathrm{g} / \mathrm{g})$ in dehulled Lameso variety from Belg season. Ahmed et al. [46] reported that wheat contains higher levels of phytic acid (6 to $10 \mathrm{mg} / \mathrm{g}$ ) than emmer wheat. Similarly, Hussain et al. [56] also reported higher $(869.2-869.4 \mathrm{mg} /$ $100 \mathrm{~g}$ ) concentrations of phytic acid in different wheat varieties and Jocelyne et al. [34] reported the phytic acid concentrations in wheat $(12.01 \mathrm{mg} / \mathrm{g})$, maize $(17.93 \mathrm{mg} / \mathrm{g})$, 


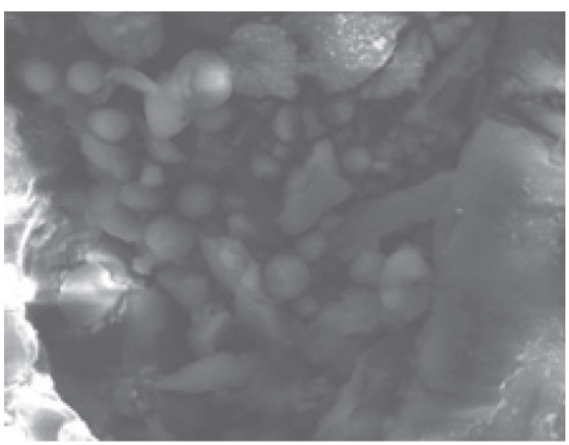

(a)

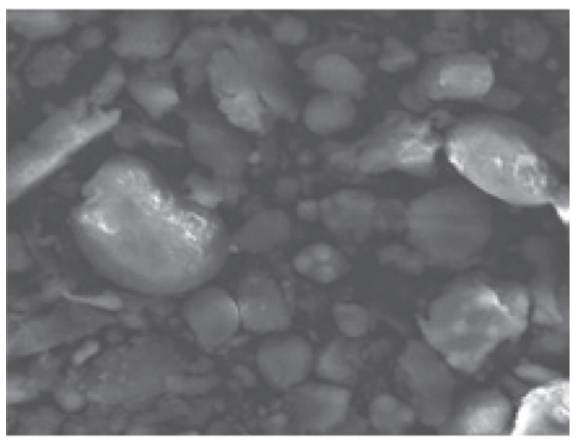

(c)

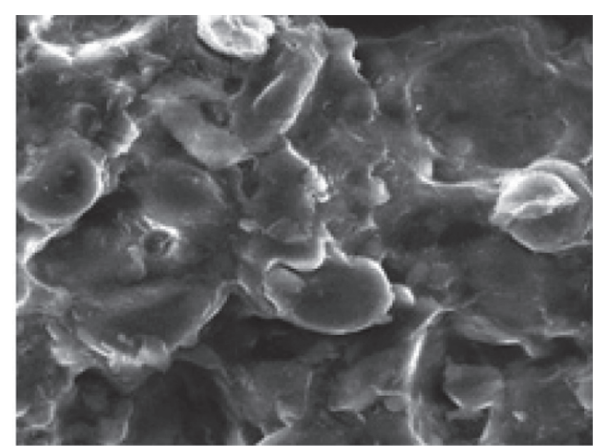

(b)

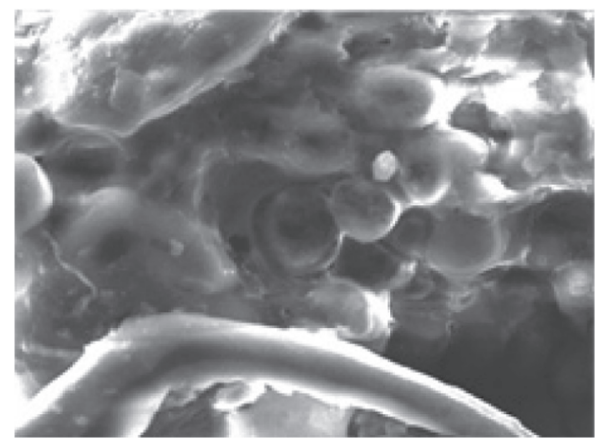

(d)

FIGURE 1: SEM of samples showing starch granules and proteins of emmer varieties: (a) Hydroo, (b) local landrace, (c) Lameso, and (d) Sinan 01.

sorghum $(15.99 \mathrm{mg} / \mathrm{g})$, and millet $(28.14 \mathrm{mg} / \mathrm{g})$ which are higher than the present results of emmer wheat. Many factors, such as genetics, growing season, type of soil, and fertilizer application, are responsible for the phytic acid content and phosphorus levels in cereals [57].

3.8. Antioxidant Property. The ANOVA revealed that interaction of grain types, varieties, and growing seasons had highly significant $(P \leq 0.01)$ effect on antioxidant activity of the studied emmer wheat samples (Table 7). The antioxidant activity ranged from $4.63 \mathrm{mg}$ Trolox/ $\mathrm{kg}$ to $17.38 \mathrm{mg}$ Trolox/ $\mathrm{kg}$ with the highest $(17.38 \mathrm{mg}$ trolox $/ \mathrm{kg}$ ) observed in the hulled local landrace from Meher season and the lowest (4.63 mg Trolox/kg) in dehulled Hydroo variety from Meher season. The results of antioxidant activity of emmer wheat showed that the dehulled grains had higher activity than the hulled ones. The variation of antioxidant activity in varieties grown in different seasons could be due to the stress factors of weather conditions during the vegetative period. Lachman et al. [58] found a much higher antioxidant activity of emmer wheat varieties ( 217.3 to $257.6 \mathrm{mg}$ trolox $/ \mathrm{kg}$ ) compared to the results of the present study.

\subsection{Scanning Electron Microscopy Study of Emmer Wheat} Flour Samples. The SEM images of emmer wheat varieties showed a difference in starch granules and presence of protein within the endosperm. Figure 1(a) shows low protein content $(9.23 \%)$ of Hydroo variety of emmer wheat. Both large and small starch granules are clearly visible, where a small number of round and angular particles in lighter shade denote the protein bodies. The image also shows that, inside the cell, starch granules and protein bodies existed as discrete particles without much coherence.

Figures 1(b) and 1(c) show the protein contents of local landrace $(15.9 \%)$ and Lameso variety $(16.01 \%)$ of emmer wheat. The image shows the starchy endosperm containing both large and small starch granules. Despite a relatively high protein level, the cell elements are more or less the same as in Figure 1(a). The distribution of protein is in the forms of protein bodies and paste spread between the starch granules.

Figure 1(d) shows Sinana 01 variety of emmer wheat with high content of protein (17.82\%). The protein bodies do not appear as separate particles but as fluid distributed between the starch granules and covering them completely. The content of the cell is much more coherent than those of the cells shown in Figures 1(a), 1(b), and 1(c)) The compact structure and the absence of voids between the starch granules show the vitreous appearance of emmer wheat variety. Heneen and Brismar [59] reported SEM analysis of rye, wheat, and triticale. In rye, the matrix was in the form of separated patches due to the low protein content, whereas wheat and triticale had continuous protein in starch granules.

\section{Conclusions}

The study was conducted to determine the physicochemical properties of emmer wheat varieties grown in Ethiopia. It aimed to analyse the effect of growing seasons, grain types, and varieties on physical properties, proximate composition, 
mineral composition, bioavailability of iron, calcium and zinc, amino acid composition, vitamin B complex composition, antinutritional factors, and antioxidant properties of emmer wheat varieties. The study found the following.

First the interaction of growing seasons, varieties, and grain types in Ethiopian emmer wheat had highly significant effects.

Second, growing seasons had a significant effect on physical properties, proximate composition, mineral composition, bioavailability, amino acid composition, and vitamin B complex of emmer wheat varieties and Meher/Belg growing season has recorded higher or lower characteristics.

Third, there is a significant difference in physical properties, proximate composition, mineral composition, and antinutritional and antioxidant properties between hulled and dehulled grains. For example, dehulled Sinana 01 variety had the highest proximate composition (crude protein, fat, crude fiber, ash, energy, gluten, and vitamins B2 and B6 content), and amino acids (aspartic, arginine, threonine, proline, and isoleucine), although high composition of some minerals (iron and potassium) was found in the hulled grain. The highest concentrations of minerals (phosphorus, copper, zinc, magnesium, sulphur, and calcium) and vitamin B3 were in dehulled Lameso varieties collected from the Belg season. Additionally, the highest concentration of vitamin B1 was in the same variety as hulled grain grown in Meher season. This study also concluded that the emmer wheat samples showed good bioavailability of minerals ( $\mathrm{Fe}, \mathrm{Zn}$, and $\mathrm{Ca}$ ). The significant differences among the analysed quality parameters were due to genetic variations between the varieties and growing seasons, which have relation to temperature.

In general, the current study demonstrated that Sinana 01 variety from Meher season had recorded the highest amount of the majority of proximate compositions and vitamins B2 and B6. The Hydroo varieties from the Meher season recorded the highest content of the studied amino acids and physical properties. The majority of the minerals are observed highest in Lameso and Sinana 01 varieties from Belg season. Ethiopian emmer wheat, as ancient wheat, has a unique composition, which is rich in protein, fiber, minerals, amino acids, and B complex vitamins and poor in antinutritional factors.

\section{Data Availability}

All data obtained are included in this manuscript

\section{Conflicts of Interest}

The authors declare that they have no conflicts of interest.

\section{Authors' Contributions}

The authors' contributions are as follows: Bethlehem Melese, conceptualization, methodology, investigation, and original draft preparation; Neela Satheesh, conceptualization, methodology, formal analysis, and writing-reviewing; Solomon Workneh Fanta, conceptualization, methodology, supervision, writing-reviewing, and resources; and Zewdie Bishaw, resources and writing-reviewing and editing.

\section{Acknowledgments}

All authors are grateful to the Sinana Agriculture Research Centre, Ethiopia, for providing experimental grain samples of four emmer wheat varieties. The authors are also thankful to ICARDA and Ethiopian Institute of Agricultural Research (EIAR) for partial financial support of this research. The authors are also grateful to SIGMA Laboratories, India, for helping in the analysis of emmer wheat grains. Finally, the authors are grateful to Faculty of Chemical and Food Engineering, Bahir Dar Institute of Technology, Bahir Dar University, for providing the facilities to conduct this research work.

\section{References}

[1] M. Rohi, I. Pasha, M. S. Butt, and H. Nawaz, "Variation in the levels of B-vitamins and protein content in wheat flours," Pakistan Journal of Nutrition, vol. 12, no. 5, pp. 441-447, 2013.

[2] H. P. Olmo and N. W. Simmonds, Evolution of Crop Plants, Longman, London, UK, 1976.

[3] S. Dhanavath and U. J. S. Prasada Rao, "Nutritional and nutraceutical properties of Triticum dicoccumWheat and its health benefits: an overview," Journal of Food Science, vol. 82, no. 10, pp. 2243-2250, 2017.

[4] J. Lachman, J. Musilová, Z. Kotíková, K. Hejtmánková, M. Orsák, and J. Přibyl, "Spring, einkorn and emmer wheat species - potential rich sources of free ferulic acid and other phenolic compounds," Plant Soil and Environment, vol. 58, no. 8, pp. 347-353, 2012.

[5] L. S. Zaremba and W. H. Smoleński, "Optimal portfolio choice under a liability constraint," Annals of Operations Research, vol. 97, no. 1-4, pp. 131-141, 2000.

[6] CSA, Central Statistical Agency Report on Area and Production of Major crops, The Federal Democratic Republic of Ethiopia Statistical Bulletin, Addis Ababa, Ethiopia, 2016.

[7] B. Melese, N. Satheesh, and S. W. Fanta, "Emmer wheat-an ethiopian prospective: ashort review," Annals of Food Science and Technology, vol. 20, no. 1, pp. 89-96, 2019.

[8] A. C. D'Andrea and H. Mitiku, "Traditional emmer processing in highland Ethiopia," Journal of Ethnobiology, vol. 22, no. 2, pp. 179-217, 2002.

[9] M. M. I. Chowdhury, R. I. Sarker, B. K. Bala, and M. A. Hossain, "Physical properties of gram as a function of moisture content," International Journal of Food Properties, vol. 4, no. 2, pp. 297-310, 2007.

[10] M. Tavakoli, H. Tavakoli, A. Rajabipour, and H. Ahmadi, "Moisture-dependent physical properties of barley grains," International Journal of Agriculture and Biological Engineering, vol. 2, no. 4, pp. 84-91, 2009.

[11] AOAC, Association of Official Analytical Chemists, AOAC, Washington, DC, 17th ed. edition, 2000.

[12] E. Onyeike and U. Uzoka, "Nutritional quality of foods formulated from cowpea-millet-crayfish mixtures," Global Journal of Pure and Applied Sciences, vol. 12, no. 4, pp. 513519, 2006.

[13] D. R. Osborne and P. I. Voogt, The Analysis of Nutrients in Foods, pp. 24-28, Academic Press Inc. (London) Ltd, London, UK, 1978. 
[14] AACC, Approved Methods of the American Association of Cereal Chemists, AACC, St. Paul, MN, USA, 10th ed. edition, 2000.

[15] S. Anna and P. Pohl, "Simple and fast sample preparation procedure prior to multi-element analysis of slim teas by ICP OES," Food Analytical Methods, vol. 6, 2014.

[16] S. Ndaw, M. Bergaentzle, D. Aoude-Werner, and C. Hasselmann, "Extraction procedures for the liquid chromatographic determination of Thiamin, riboflavin and vitamin B6 in foodstuffs," Food Chemistry, vol. 71, no. 1, pp. 129-138, 2000.

[17] I. A. Vaintraub and N. A. Lapteva, "Colorimetric determination of phytate in unpurified extracts of seeds and the products of their processing," Analytical Biochemistry, vol. 175 , no. 1 , pp. $227-230,1988$.

[18] FAO, Global Food Composition Database for Phytate Version 1.0 (Phyfoodcomp1.0), FAO; Children's Hospital \& Research Center at Oakland, Rome, Italy, 2018.

[19] S. B. Kedare and R. P. Singh, "Genesis and development of DPPH method of antioxidant assay," Journal of Food Science \& Technology, vol. 48, 2011.

[20] M. Hejcman and P. Hejcmanová, "Yield and nutritive value of grain, glumes and straw of Triticum dicoccum produced by prehistoric Technology in comparison to T. Aestivum produced by modern Technology," Interdisciplinaria Archaeologica Natural Sciences in Archaeology, vol. 5, no. 1, pp. 31-45, 2015.

[21] M. Babic, J. Turan, and M. Radojcin, "Physical and stressstrain properties of wheat (Triticum aestivum) kernel," Journal of the Science of Food and Agriculture, vol. 91, no. 7, pp. 1236-1243, 2011.

[22] M. Guner, "Pneumatic conveying characteristics of some agricultural seeds," Journal of Food Engineering, vol. 80, no. 3, pp. 904-913, 2018.

[23] E. Kolankowska, D. J. Choszcz, and P. Markowski, "An analysis of selected physical properties of ancient wheat species," Sustainability, vol. 9, no. 11, pp. 2-11, 2017.

[24] A. Taner, "Classification of varieties of grain species by artificial neural networks," Agronomy, vol. 7, 2018.

[25] H. Wang, L. Wu, M. Cheng et al., "Coupling effects of water and fertilizer on yield, water and fertilizer use efficiency of drip-fertigated cotton in northern Xinjiang, China," Field Crops Research, vol. 219, pp. 169-179, 2018.

[26] S. O. Nelson, "Dimensional and density data for seeds of cereal grain and other crops," Transactions of the American Society of Agricultural Engineers, vol. 45, no. 1, pp. 165-170, 2002.

[27] M. Markowski, K. Żuk-Gołaszewska, and D. Kwiatkowski, "Influence of variety on selected physical and mechanical properties of wheat," Industrial Crops and Products, vol. 47, pp. 113-117, 2013.

[28] M. Molenda, J. Horabik, "Part1: characterization of mechanical properties of particulate solids for storage and handling," in Mechanical Properties of Granular Agro- Materials and Food Powders for Industrial Practice Molenda, J. Horabik, Ed., pp. 210-222, Institute of Agrophysics Polish Academy of Sciences, Lublin, Poland, 2005.

[29] S. Nasreen, "Effects of storage period and temperature on seed viability of wheat," Pakistan Journal of Biological Sciences, vol. 2, no. 4, pp. 1492-1493, 1999.

[30] M. Lacko-Bartošová and V. Čurná, "Nutritional characteristics of emmer wheat varieties," Journal of Microbiology, Biotechnology and Food Sciences, vol. 4, no. 3, pp. 95-98, 2015.
[31] V. Giacintucci, L. Guardeño, A. Puig, I. Hernando, G. Sacchetti, and P. Pittia, "Composition, protein contents, and microstructural characterisation of grains and flours of emmer wheats (Triticum turgidum ssp. dicoccum) of the central Italy type," Czech Journal of Food Sciences, vol. 32, no. 2, pp. 115-121, 2014.

[32] A. Bordoni, F. Danesi, M. Di Nunzio, A. Taccari, and V. Valli, "Ancient wheat and health: a legend or the reality? A review on KAMUT khorasan wheat," International Journal of Food Sciences \& Nutrition, vol. 68, no. 3, pp. 278-286, 2017.

[33] V. Sterna, S. Zute, and L. Brunava, "Oat grain composition and its nutrition benefice," Agriculture and Agricultural Science Procedia, vol. 8, pp. 252-256, 2016.

[34] R. Jocelyne, K. Béhiblo, and A. Ernest, "Comparative study of nutritional value of wheat, maize, sorghum, millet, and fonio : some cereals commonly consumed in côte d 'I voire," European Scientific Journal, vol. 16, no. 21, pp. 118-131, 2020.

[35] C. R. Babu, H. Ketanapalli, S. K. Beebi, V. C. Kolluru, W. Bran, and C. Endosperm, "Wheat bran-composition and nutritional quality: a review," Advances in Biotechnology and Microbiology, vol. 9, no. 1, pp. 21-22, 2018.

[36] USDA, US Department of Agriculture, Agricultural Research service, USDA National Nutrient Database For Standard References, USA, 2016.

[37] W. Biel, K. Kazimierska, K. Kazimierska, and U. Bashutska, "Nutritional value of wheat, triticale, barley and oat grains," Acta Scientiarum Polonorum Zootechnica, vol. 19, no. 2, pp. 19-28, 2020.

[38] P. Konvalina, "Quality evaluation of emmer wheat genotypes based on rheological and Mixolab parameters," Food analysis Food quality and Nutrition, vol. 37, no. 3, pp. 192-198, 2010.

[39] V. Zecevic, J. Boskovic, D. Knezevic, D. Micanovic, and S. Milenkovic, "Influence of cultivar and growing season on quality properties of winter wheat," Triticum aestivum $L$.), vol. 8, no. 21, pp. 2545-2550, 2013.

[40] A. R. Piergiovanni, R. Rizzi, E. Pannacciulli, C. D. Gatta, and E. Pannacciulli, "Mineral composition in hulled wheat grains: a comparison between emmer (Triticum dicocconSchrank) and spelt (T. speltaL.) accessions," International Journal of Food Sciences \& Nutrition, vol. 48, no. 6, pp. 381-386, 1997.

[41] F. J. Zhao, Y. H. Su, S. J. Dunham, Z. Bedo, S. P. Mcgrath, and P. R. Shewry, "Variation in mineral micronutrient concentrations in grain of wheat lines of diverse origin," Journal of Cereal Science, vol. 49, no. 2, pp. 290-295, 2009.

[42] D. Rubene and P. Kuka, Minerals in Oats, Barley and Wheat Grains, pp. 75-78, Research for Rural Development; Latvia University of Agriculture, Jelgava, Latvia, 2006.

[43] E. Suchowilska, M. Wiwart, W. Kandler, and R. Krska, "A Comparison of Macro- and Microelement concentrations in the whole grain of four Triticum species," Plant Soil and Environment, vol. 58, no. 3, pp. 141-147, 2012.

[44] P. J. White, M. R. Broadley, and M. R. Broadley, "Biofortification of crops with seven mineral elements often lacking in human diets - iron, zinc, copper, calcium, magnesium, selenium and iodine," New Phytologist, vol. 182, no. 1, pp. 49-84, 2009.

[45] B. T. T. Tran, T. R. Cavagnaro, J. A. Able, and S. J. WattsWilliams, "Bioavailability of zinc and iron in durum wheat: a trade-off between grain weight and nutrition?" Plants, People, Planet, vol. 3, no. 5, pp. 627-639, 2020.

[46] A. Ahmed, F. M. Anjum, S. Ur Rehman, M. A. Randhawa, and U. Farooq, "Bioavailability of calcium, iron and zinc fortified whole wheat flour chapatti," Plant Foods for Human Nutrition, vol. 63, no. 1, pp. 7-13, 2008. 
[47] S. Hussain, M. Maqsood, and L. Miller, "Bioavailable zinc in grains of bread wheat varieties of Pakistan," Cereal Research Communications, vol. 40, no. 1, pp. 62-73, 2012.

[48] A.-S. Sandberg, "Bioavailability of minerals in legumes," British Journal of Nutrition, vol. 88, no. S3, pp. 281-285, 2002.

[49] V. Castro-Alba, C. E. Lazarte, B. Bergenståhl, and Y. Granfeldt, "Phytate, iron, zinc, and calcium content of common Bolivian foods and their estimated mineral bioavailability," Food Sciences and Nutrition, vol. 7, no. 9, pp. 2854-2865, 2019.

[50] S. Zafar, N. Naz, S. Nazir, M. Abbas, and A. M. Khan, Analysis of Selected Amino Acids in Different Varieties of Wheat AvailableChromatography Reserch International, Punjab, Pakistan, 2014.

[51] P. Konvalina and Z. Stehno, "Amino acid compositon of emmer," Seria Agronomie, vol. 51, pp. 1-9, 2007.

[52] B. Jas'kiewicz and M. Szczepanek, "Amino acids content in triticale grain depending on meteorological, agrotechnical and genetic factors," Research for Rural Development, vol. 2, no. 5, pp. 28-34, 2018.

[53] S. Alijosius, R. Gruzauskas, A. Dauksiene, and V. Sasyte, "The application of triticale in nutrition of broiler chickens," Veterinarija ir Zootechnika, vol. 73, no. 95, pp. 3-8, 2016.

[54] V. Piironen, A. M. Lampi, and P. Ekholm, "Micronutrients and phytochemicals in wheat grain," in Wheat Chemistry and Technology, K. Khan and P. R. Shewry, Eds., pp. 179-185, American Association of Cereal Chemists, St. Paul. MI, USA, 4th Edn. edition, 2006.

[55] L. Dykes and W. Rooney, "Phenolic compounds in cereal grains and their health benefits," Cereal Foods World, vol. 52, no. 3, pp. 105-111, 2007.

[56] I. Hussain, M. B. Uddin, and G. Aziz, "Optimization of antinutritional factors from germinated wheat and mungbean by Response Surface Methodology," International Food reserch Journal, vol. 18, no. 3, pp. 957-963, 2011.

[57] M. Nadeem, M. Anjum, and S. Hussain, "An overview of antinutritional factors in cereal grains with special reference to wheat-A review an overview of anti-nutritional factors in cereal grains with special reference to wheat-A review," Pakistan Journal of Food Sciences, vol. 20, no. 1-4, pp. 54-61, 2010.

[58] J. Lachman, M. Orsák, V. Pivec, and K. Jírů, “Antioxidant activity of grain of einkorn (Triticum mono-coccum L.), emmer (Triticum dicoccum schuebl [schrank]) and spring wheat (Triticum aestivum L.) varieties," Plant Soil and Environment, vol. 58, no. 1, pp. 15-21, 2012.

[59] W. K. Heneen and K. Brismar, "Scanning electron microscopy of mature grains of rye, wheat and triticale with emphasis on grain shrivelling," Hereditas, vol. 107, no. 2, pp. 147-162, 1987. 